\title{
On analogical arguments: Organizing logical and conceptual problems in sections 18 and 19 of Schopenhauer's The World as Will and Representation ${ }^{1}$
}

\author{
Marcos Silva \\ PhD Student in PUC-Rio, holder of a CAPES Scholarship in 2008 and 2012, \\ and of a DAAD Scholarship in 2009 and 2011. \\ E-mail: marcossilvarj@hotmail.com
}

\begin{abstract}
Here I list and organize some logical and conceptual problems in Section 18 (about the cognoscibility of the thing in itself) and Section 19 (about the extension of this result to the world) in Schopenhauer's main work. When Schopenhauer put out the analogical argument for the responsibility for transmitting (übertragen) the problematic identification thing in itself/will, he brought to his philosophy the following fragile points of such an argument: (i) the logical invalidity; (ii) the lack of criterion for the extension scope; (iii) the indeterminacy of what is really being extended; (iv) the unrestricted character of his analogical extension; (v) the indirect nature of his argument (for avoiding the solipsism); and (vi) the collapse of what is being extended. I then try to point out why - despite these logical fragile points - the analogical argument seems not to be problematic at all to Schopenhauer.
\end{abstract}

KEY-WORDS: Analogical arguments, Solipsism, Thing in itself.

RESUMO: Aqui listo e organizo alguns problemas lógicos e conceituais dos parágrafos 18 (sobre a cognoscibilidade da coisa em si) e 19 (sobre a extensao deste resultado ao mundo) na obra principal de Schopenhauer. Quando Schopenhauer coloca a responsabilidade no argumento por analogia de transmitir (übertragen) a problemática identificação coisa em si/vontade, ele traz para a sua Filosofia os seguintes pontos frágeis deste argumento: (i) a invalidade lógica; (ii) a falta de critério para o alcance da extensao; (iii) a indeterminação do que está sendo realmente extendido; (iv) o caráter irrestrito da extensão analógica; (v) a natureza indireta do argumento (para evitar o solipsismo); e (vi) o colapso do que está sendo extendido. Assim tento apontar por que, apesar destes pontos frágeis, este argumento por analogia parece nao ser de forma alguma problemático para Schopenhauer.

PALAVRAS-CHAVE: Argumentos por analogia, solipsismo, coisa-em-si.

“O que tem de ser tem muita força."(Graciliano Ramos, In: Angústia)

This paper begins with the instructive search for a common logical structure among the analogical arguments present in sciences and daily discourses, highlighting its negative and positive aspects. Here we focus on the intuition that the same discursive structure brings the same problem to a theoretical context, i.e., a general structure means general

\footnotetext{
${ }^{1}$ I am highly indebted to the constructive criticism of Prof. Dra. Vera Cristina Bueno, Prof. Dra. Déborah Danowsky, Prof. Dr. Luiz Carlos Pereira and Prof. Dr. Mathias Kossler on early versions of this article.
} 
problems. Consequently, I try to find this "portable" common logical form for the analogical tools in the argumentation used by Schopenhauer in Section 19 of The World as Will and Representation ${ }^{2}$. This approach reveals that there are the same underlying problems, besides other specific ones, which emerge from the generality of what is being tried there: to hold that everything in the world has essentially the same will as that which I find in my body. In German, Übertragung means an extension, a transmission, or transference - meanings that appear clearly in the expression im übertragenen Sinn, used to show an analogy between individuals or domains by means of resemblance, transporting the meaning of a context to another. The aim in this part of the paper is to investigate the extent to which the fundamental problems in the analogical argument can "contaminate" Schopenhauer's philosophy. In order to realise this aim, I explore two meanings of Übertragung: the meaning of transmission, in the case of extension and transference of results or properties by means of an analogy, and the meaning of contamination. I then highlight the organic character of Schopenhauer's Philosophy and possible threats generated by the analogical argument against its "organism" health. In Section 19 there is an obvious case of an analogische Übertragung, that is, an extension or transmission of properties via analogy or resemblance between elements of the domain in question. The domain here is the world, and the elements, everything that compounds or can compound our empirical experience.

Moreover, in order to understand Section 19 we have to examine Section 18 in detail. That is why I try to deal with some more general problems with the thesis presented in Section 18 relating to the knowledge of the thing-in-itself, which "der eigentümlichste und wichtigste Schritt meiner Philosophie ist, nämlich den von Kant als unmöglich aufgegeben Übergang von der Erscheinung zum Dinge an $\operatorname{sich}^{3} \%$. The problems in these two sections are too robust and central to be overlooked, even by authors and readers that concentrate themselves on Schopenhauer's ethics or aesthetics. It is not problematic to call this pair of sections problematic in his work. Volker Spierling in his Lexikon to Schopenhauer recognizes this fact:

\footnotetext{
${ }^{2}$ For purposes of convention and efficiency, when referring to Schopenhauer's main work The World as Will and Representation, I will write WWV. Additionally, I will use the numbers I and II to designate respectively the volume one or two of WWV. The second volume (published in 1844) is enhanced with supplementary chapters to the first sections, the main part of his work, published in 1819. All translations from texts originally written in Portuguese are my own.

${ }^{3}$ SCHOPENHAUER, WWV II, p. 233.
} 
Wie kann dieser Gedanke von der doppelten Leiberfahrung für die Erkenntnis des Dings an sich genutzt werden? Schopenhauer steht hier mitten in der Schmiede seiner Metaphysik. Er prüft die Werkzeuge. Womit lässt sich das Innere der Dinge aufschließen? Eine unmittelbare Erkenntnis der Innenseite der Natur kommt nicht in Frage, weil der Mensch über kein übersinnliches Erkenntnisvermögen verfügt.(..) Gemeint ist mit „Innenseite“ das, was unabhängig vom Bewusstsein, vom Intellekt ist, was also an sich ist: Ding an sich. Das Werkzeug, zu dem Schopenhauer greift, ist der Analogieschluss. Diese methodische Entscheidung gehört sicherlich zu den fragwürdigsten Seiten seiner Philosophie. (...) Die Welt als Vorstellung hat - analog zum menschlichen Leib - noch eine andre Seite: die Welt als Wille ${ }^{4}$.

We can notice in this way that the problem of the thing-in-itself in other bodies and the problem of the will in other bodies are not the same problem. They can stand separately, keeping in mind one important further point: the second problem depends on the first. So, there seems to be no controversy among the Interprets and even literally in the Schopenahuer's Philosophy that Section 19 is the locus classicus of the analogical procedure occurrence to extend the philosophical truth of Section 18 (i.e. that the thing-in-itself $=$ will) to all things in the world ${ }^{5}$. It is for their resemblance to me, to my extended and consecutive body, subject to cause and effects, that I justify that other things of the world have the same essence that I have just found in me through introspection.

Finally, I end this paper by discussing and listing some reasons for the use of the analogical argument which, although seemingly unproblematic for Schopenhauer, is found to be weak in all secondary literature.

\footnotetext{
${ }^{4}$ SPIERLING, 2002, p. 48. My italics.

5 "Der springende Punkt, die kühne Spekulation der Metaphysik Schopenhauers besteht darin, dass das Schema der eigenen Leiberfahrung - Willensseite und Vorstellungsseite - durch einen Analogieschluss auf die gesamte Natur überträgt. Die Wille-Leib-Identität gilt als Modell für die Welt. Das, was sich uns lediglich als Vorstellung darstellt, beispielsweise andere Menschen, Tiere, Pflanzen, anorganische Natur, wird analog zur eigenen Leiberfahrung gedeutet, und um eine vorstellungsabgewandte Willensseite ergänzt. Schopenhauer unterlegt spekulativ der ganzen Welt einen Willen, der dem menschlichen Willen, wie wir ihn an uns selbst erfahren, ähnliche sein soll. Er setzt die äußere Erfahrung mit der inneren in Verbindung und macht dabei die innere Erfahrung zum Schüssel jener“ SPIERLING, 2002, p. 66.
} 
Antonio Zilhão, author of the entry "analogical argument" ${ }^{6 "}$ in the Enciclopédia de Termos Lógico-filosóficos, defines it as:

An argument that infers the satisfaction of a property $\Phi$ by an object B, using the analogy that can be verified between the object B and the object A, which we know previously that satisfy the property $\Phi$. The existent analogy between the objects $\mathrm{A}$ and $\mathrm{B}$ can be clarified in terms of the existence of a certain group of properties that is satisfied by A and by B (p. 59).

In fact, any resemblance of two objects can be considered, in an analogical argument, in order to justify the extension or transference of some other features from one to the other. Nevertheless, it is intuitive that because A resembles B in a specific quality or portion, large or small, it does not follow, necessarily, that A and B have other properties and/or relations in common. Considering this rigorously, we do not need to operate with sophisticated calculi in formal systems in order to know clearly that arguments based on the analogy of predicates shared by different objects or subjects are invalid arguments. That is, even if the premises (or whatever) is brought to justify the conclusion are true, the conclusion does not have to be. In other words, even if the conclusion happens to be true, just like these premises are, the truth-values are independent. We can easily think of counter-examples which can clearly show their vulnerability.

\footnotetext{
${ }^{6}$ There are historically three kinds of analogical arguments: one with platonic origin, with an emphasis on the proportionality relation between terms or domains to be compared with another. We say, for example, that $A$ is related to a $P$, just like a $B$ is related to a $Q$, in such a way that the relationships between $P A$ and $Q B$ are analogous or alike. There is a second kind of analogical argument present in the medieval theology, the emphasis of which is to be found in the relation of participation or imitation. We say, for example, that creatures are good because their Good imitates God's Goodness, in such a way that the creatures' and God's Goodness are analogous or alike. Finally, we have a third kind of analogical argument that circumscribes this paper, which has its emphasis in the notion of ascribing a property or relation via community or resemblance between different investigated domains or individuals. We intend to justify the passage or transference of some features of a domain to another via some relevant resemblance between them. There are traditional examples of disputes about the analogical reasoning in the philosophical field, such as in the field of the English empiricism. A common onus to the primacy of the sensory experience in the epistemology is to interdict, for example, the knowledge of minds external to mine. It is through an analogy to my body and my behavior that I can ascribe mind to other human beings, even if I do not truly have any directly or sensorial access to their minds. In this way we can avoid solipsism as a threat to the empiricism legitimacy. It can be revealing to note that both the form of the argument (via analogy) and its itinerary (the comparison of others bodies with mine), will reappear in the Schopenhauer's Philosophy, in a great measure, in order to overcome the same undesired alternative (the solipsism). Here we can also be more speculative. We can even hold the Tractatus of Wittgenstein - informed as it was by Schopenhauer - as another philosophical perspective that deals with an analogy, but between logical structures via a Bildkonzeption der Sprache (cf. 2.1-2.225), and a peculiar form of solipsism ( $c f .5 .6-5.641)$.
} 
It seems clear that there is an intuitive restriction on the validity of - or an accusation of illegitimacy against - analogical arguments, even in common daily speech. This fact shows that - at least in this point - a formal restriction can be altogether justified and accompanied by intuitive elements of discourses in natural language. For example, one can think of such a situation: a guest at a party asks his friend if the beer inside his cup is cold or not. The friend answers that it is not, wondering as he does: "how do you know that I am drinking beer, if my cup is completely dark?" Here is a perfect scenario, in which the first character can use analogies between his own cup, and its contents, to justify his correct guess about the content of his friend's, thinking as he does: "Because our cups are similar, they resemble each other, and my beer is too warm for me, I believe I will complain about it". I assume that the two example characters here do not see necessity or certainty in this argument. They do not hold this inference as necessary, correct or strictly valid or even legitimate, although there is a certain degree of contextual relationship between premises and conclusion. Surely, they would not think something like this: "Our cups are similar; therefore they "have to" contain the same liquid". But, rather: "Our cups are similar; therefore "it is possible" that they have the same content". The emphasis here has to be found in this predication of modality: that is that "it is possible", "it is likely", "it is probable" or - conversely - "it is not necessary". Nothing like "has to be" or "must be" or "surely" in a strong sense could possibly be acceptable in this situation be that for the friends, listeners-in to their conversation, or logicians. Similarity between domains or objects is neither a sufficient nor a necessary condition: using the same example, even if the cups were different, they could still have the same content.

Many further circumstances or forms of evidence that can be listed may make the argument stronger or make the analogical implication or inference more certain, even without providing it with necessity or validity. There are several factors which affect the probability of analogical arguments. Everyone at the party knows that each kind of cup being used at the party can be designated for different kinds of drinks (i.e. dark cups may be used for beer; light-colored cups for wine, and plastic cups for soft drinks etc.). It may also be that one of the friends knows that the other only drinks beer at parties. Or the guest may even know that only beer and soft drinks are being served at the party - a situation that restricts the range of potential beverages to just two choices. In each case, even if we could 
list all the additional circumstances, or good reasons, and relevant contextual evidence in order to supply the analogical argument or reasoning (i.e. the two guests have the same type of cups, therefore they are drinking the same type of drink), these would not be sufficient to conduct us necessarily to the conclusion based on the premises. For it is possible that the friend's cup could ultimately contain any other liquid, or non-liquid, or it may even be empty.

Nevertheless, analogical arguments, in spite of being invalid, are not epistemological innocuous, just like related inductive and abductive arguments. A fortiori, analogical extensions can play a positive and decisive role, including within sophisticated domains of discourse. They can act for example, as, methodological conductors in scientific research. Any correlate idea can be explored by a scientist or become a topic for consideration at a meeting of biotechnologists. At a hypothetical meeting, scientists may find that as "the vaccination functions with pigs and apes, it is - therefore - extremely likely that it will work in human beings as well, because their immunological systems are alike". There is no strict logical necessity here either. Both the scientist and the biotechnologist at the meeting know that, even when they have not studied logic more systematically. Moreover, if there were a logical necessity it would condemn experiments or empirical tests as irrelevant, as their importance comes precisely from the lack of analyticity between the premises (or what we already know) and the conclusion (what we are looking for). Clearly, the analogical argument counts in this context as a methodological north or strategic bridge which justifies what the next most suitable research step should be for clinical tests. In this way, analogical research plays the role of directing our expectations, even if they will not be fulfilled in the future.

It is in no way surprising that we can uncover this reasoning in another scientific context different to laboratory research: Brazil, China and India all have large populations, major productive power, great levels of internal consumption, with potential to grow fast, large offer of commodities, which can supply their internal market as well as external demands. Keeping these factors in mind, the three nations could, therefore, be considered as belonging to the same category or type of country, that of emerging countries. So far so good as it seems trivial to hold that empirical observations contribute to the sense composition of empirical propositions and to the classification of items in a more or less 
organized, not-definite or not-exhaustive way. Nevertheless, no study in Economics would infer a conclusion about the stock market of one country based on that of another without observing some additional resemblances, such as geopolitical, economical or financial factors. For example, no reliable economist would declare that "The Brazilian stock market will follow the Chinese stock market". Such an affirmation would be weak and highly disputable. For, notwithstanding their many striking resemblances, there are indeed many differences between the two countries and their economies which justify skepticism when making assertions and reasoning based on such analogies. In principle, other inductive arguments, or additional relevant observations or forms of evidence can systematically increase the plausibility or probability of analogical arguments, but these are not sufficient to sustain any necessity between the premises and the conclusion. To continue on with our example, it is plausible that an economist may think that "As in previous economic crises similar to this current one, emergent countries (because of their similar production and consumption strength) have recovered faster than other nations, therefore, emergent countries like China, India and Brazil can recover faster now." The modalization is necessary once again. "They can be free from the crisis faster than other countries, but it is not necessary". Indeed, counter-examples can be taken from Russia - a nation similar to the emergent countries in terms of the aforementioned criteria but also different, as there is no foreseeable date for satisfactory economic recovery in Russia as yet.

Although it may be appealing, it is neither the degree of resemblance, nor the iteration of additional circumstances, nor the supplementation by inductive arguments that will bring necessity to the analogical arguments. In the natural sciences, this "logical fact" is advantageous, since scientists deal systematically with models that can and must be substituted by other ones that are likely to be more adequate to describe and predict the state of a specific field under observation - whether in terms of investigating immunological systems or macroeconomic debates. This fact clearly shows that there are degrees of likeability that will sustain the strength of the modality in the conclusion from the assumption or truth of the premises.

The problem with the analogical problems is not restricted to its validity in a logical sense. Rather, a great deal of its weakness is in the argument's foundation - founded as it is on a lack of criteria - and justification of the extension scope of properties or attributes via 
resemblance. If this scope has to be restricted at any time through questions such as: How many dark cups are there being used at the party? Are there some that are not dark at all? Is the vaccination suitable for all human beings, irrespective of their age, ethnic background or gender? or What about emergent countries which are not democracies? Is the economical resemblance strong enough to justify inferences about one of the countries based on another?... Depending on the relevance of the criteria or on the objects of the referential basis, the analogical extension may be too restricted or too permissive. In extreme cases, it can make the group of predicates (or the analytical base) somewhat trivial, since all the objects in the domain discourse could be found to have a common predicate, as can, indeed, every object in any possible domain when considered in terms of loose logical properties (such as "being identical to itself" or "not being strictly contradictory").

Another not strictly logical problem with analogical argumentation is in the indeterminacy of what is being extended: More than what one previously wanted (or expected) to be extended can be extended. For as, just as with the friend from our example who made assumptions about the contents of his friend's cup based on the existence of impurities in his own; or with the scientists who accept that some peculiar features of a pig's organism also belong to apes and - by extension - to human beings; or in the unjustified belief that the Chinese political regime is as democratic as India's, just because they share some productive resemblances. Many conclusions - robust or not - that do not follow from the premises can be generated and, while more or less artificial, all of them show the fragility of analogical arguments and the vague points in analogical reasoning.

What these examples illustrate is that the transference of any predicate or relation from any one object, individual, aggregate, phenomenon, or domain to another is not totally reliable. Such transference, therefore, needs a reasonable and relevant methodological justification. Otherwise, it can be too vulnerable to numerous counter-examples. Analogy based on the resemblance of predicates is neither sufficient nor necessary to invoke necessity between implications or inferences in any discursive domains - be they sophisticated (such as in the fields of biology and economics) or trivial (such as a conversation amongst friends at a party). In fact, it is problematic to depend on an invalid argument when we deal with central themes of a universe of discourse or when we are in a domain in which central theses are involved in a theory. Indeed, a simplistic presumption 
based on an analogical argument can weaken the entire discourse, if its use is not justified or relevantly supplied by other arguments or evidence.

So far, I have tried to examine how arguments in extra-philosophical domains that involve analogies have problems. I have also tried to show the extent to which the structure of analogy seems to repeat itself; unfolding, as it does, in such a manner that its general form can have a certain contextual autonomy ${ }^{7}$. Consequently, my natural next step is to assume that this common structure can be portable and applicable in the analysis of arguments in which analogical reasoning appear, including within the discourse of Philosophy. In fact, all these problems with analogical arguments appear in the background of Section 19 of Schopenhauer's WWV I - a problematic but central or key section in the work. In short, in this section, the philosopher extends the already problematic result of Section 18 (thing-in-itself as will) to all phenomena in the world.

Moreover, I find that, Schopenhauer, besides inheriting proper and portable problems of analogical extensions, presents others of his own in his philosophy. In fact, in Section 19 of WWV I, there are structural problems with the analogical reasoning - as we have already expected. These being: (i) logical invalidity; (ii) lack of criteria for the extension scope; and (iii) the indeterminacy of what is being extended. But even more: (iv) the unrestricted character of its analogical extension (all the phenomena of the world) that blurs, perhaps definitively, the different and vast resemblance degrees that composes the world (v) the argument's indirect character. - its strength and defense by the philosopher coming rather from the alternative's unacceptability (solipsism). And, finally, (vi) the collapse - perhaps improper, but justified by Schopenhauer's transcendental considerations - of what is being extended by the analogy to one's body.

At this point, this last assertion (vi) deserves already a short explanation. In general, all the arguments previously presented do not collapse what is being extended into a same entity or same thing. Although the aim with our first example is to maintain that there is the same kind of liquid in the cups, they do not have to have the same source; for example, they

\footnotetext{
${ }^{7}$ Antonio Zilhão illustrates this point in his entry to the already cited Enciclopédia. 
needn't necessarily have come from the same fridge or bottle. And with the second example - although the aim is to justify clinical research on some medicines that have already been tested on animals - we do not assume there are the very same white cells that flow in the immunological systems of different species, or even in different individuals from the same species. In the third example, although we try to foresee the behavior of emergent economies in reaction to financial crises, we never assume that their economies, with their active and passive products are strictly the same ones, nor do we forget that financial markets have a great deal of autonomy and various idiosyncrasies. This kind of strong identity of what is being transmitted or extended by the analogy is not tried or even expected as a by-product in the previous arguments. Schopenhauer does defend this collapse of what is being extended in Section 19. For, even if one's will as the thing-initself is extended to all phenomena of the world by means of their phenomenal resemblance, it is strange, and even, indeed, somewhat ironic for the "world of the analogies" to demand that this to-be-extended will and the one from the investigated domain are indeed the same. Thus revealing it to be highly unlikely that the item that is being extended is the very same in all the things that are alike. Here is an additional problem which I do not find to be properly dealt with by Schopenhauer or by the secondary literature.

In her seminal book, Schopenhauer e a questão do dogmatismo, Maria Lucia Cacciola presents Schopenhauer's problematic analogical argument. In this succinct paragraph Cacciola uncovers these problems: from its logical invalidity until the indirect character of its reasoning, passing through the unrestricted extension which is insensitive for the different degrees of resemblance.

The amplification of the Will as the essence of all phenomena is established through an analogical procedure. Namely, the human body is a representation that differentiates itself from the other in respect of the knowledge relationship, being in the rest equal to any other. It is the knowledge relationship in the body which shows a double aspect: on one side, as an immediate knowledge of the will, and on the other side mediately as representation. To admit that this object differentiate itself intrinsically from all other would mean the negation of the external world reality. (...) This reality negation would consist exactly in what he calls "theoretical egoism", which is so suspicious as the "practical egoism". (...) The basis for this analogy which allows to give all phenomena the same essence as the human one is to be founded at the fact that the other 
objects, considered as representation, are identical to my body, that is, they fill the space and act through the causality law. And, in this way, just as we can know our body in two different manners, we can by means of an analogy admit that the other phenomena are, on one side, representation and on the other, "what we in ourselves call will" (...) Therefore the duplicity, in the knowledge of the being and the action in our bodies, turns out to be the key to the knowledge of the being in which phenomenon $^{8}$ (p. 50).

From this point, I intend to show that the analogical argument is too vulnerable to be so central in the Schopenhauer's Philosophy without any kind of relevant supplementation. Nevertheless, it may be revealing to investigate why this procedure does not seem to be problematic to the philosopher. Part of the answer to this question can be found in the supplementation of the missing strength in the resulting extension (will=thing in-itself) from one's body to the world by means of largely empirical observations and of clearly naturalist procedures. In other words, Schopenhauer tries to supply the deficiencies of the analogical argument with examples and observations taken from naturalist compendium and from his empirical observations in order to compound corroborative evidence. Rigorously speaking, however, the quantity of observation, although relevant, does not make his - or, indeed, any - argument valid. Another point here is that validity is not relevant in this radical field of "knowledge" in which Schopenhauer operates in Section 19 and this fact is coherent with the tenets of his Philosophy. I will return to this point in the last section of this paper.

In the middle of Section 18 supplementation, in WWV II, we can find both the problems circumscribed: The identification of the thing-in-itself with the will and the analogical extension are coordinated and interact clearly there, including the already mentioned non sequitur.

Jedoch ist die innere Erkenntnis von zwei Formen frei, welche der äußern anhängen, nämlich von der des Raums und von der alle Sinnesanschauung vermittelnden Form der Kausalität. Hingegen bleibt noch die Form der

8 CACCIOLA, 1994, p. 50. In italics, I highlight the parts that I hold as the most problematic. 
Zeit, wie auch die des Erkanntwerdens und Erkennens überhaupt. Demnach hat in dieser innen Erkenntnis das Ding an sich seiner Schleier zwar großen Teils abgeworfen, tritt aber doch noch nicht ganz nackt auf. (...) Aber dennoch ist die Wahrnehmung, in der wir die Regungen und Akte des eigenes Willens erkennen, bei Weitem unmittelbarer, als jede andere: sie ist der Punkt, wo das Ding an sich am unmittelbarsten in die Erscheinung tritt, und größter Nähe vom erkennenden Subjekt beleuchtet wird; daher eben der also intim erkannte Vorgang der Ausleger jedes andern zu werden einzig und allein geeignet ist. (...) Denn bei jedem Hervortreten eines Willensaktes aus der dunklen Tiefe unsers Innern in das erkennende Bewusstsein geschieht ein unmittelbarer Übergang des außer der Zeit liegenden Dinges an sich in die Erscheinung. Demnach ist zwar der Willensakt nur die nächste und deutlichste Erscheinung des Dinges an sich; doch folgt hieraus, dass wenn alle übrigen Erscheinungen ebenso unmittelbar und innerlich von uns erkannt werden könnten, wir sie für eben Das ansprechen müssten, was de Wille in uns ist. In diesem Sinne also lehre ich, dass das innere Wesen eines jeden Dinges Wille ist, und nenne den Willen das Ding an sich $^{9}$.

In this passage, I draw your attention to three problems (in italics above), namely: (i) even with the experience of the body working as an efficient guiding theme, given the Kantian restriction to the discovering of what Schopenhauer calls das philosophische Wahrheit, we already have the time barrier and therefore, a knowledge of the thing-in-itself as temporally conditioned, or body dependent, so to speak. It is worth asking if this taken as knowledge, though peculiar, and not adjudicative; (ii) the body being the orientation point which Schopenhauer calls the most characteristic and important step of his Philosophy, we have to assume this precarious and inadequate knowledge as the interpretative key of all things. We can see the scenario's construction here and, thus, foresee the analogical argument. (iii) Through this weak modal, "müssten", we may have a methodological justification, a protocol or notification of a possibility, or even a metaphor, another meaning of Übertragung, that cannot be grasped if we concentrate ourselves on just the argument to be used in this extension ${ }^{10}$. As we will see, we need more than this argument to make this transition more cogent.

9 SCHOPENHAUER, WWV II, p. 230-1.

10 This weak modalization also appears in the EFJ Payne's corresponding translation with "we should be obliged to": "Accordingly, the act of will is indeed only the nearest and clearest phenomenon of the thing in itself, yet it follows from this, if all the other phenomena could be known by us just as immediately and intimately, we should be obliged to regard them precisely as that which the will is in us." (p. 197, WWV II, trans. EFJ Payne.). 
Before we investigate the logical and metaphysical problems that appear in Section 19 more carefully, it may be instructive to list and organize some more general problems about the problematic Schopenhaurian thesis of the knowledge of the thing-in-itself. It is worth noting that there is a kind of asymmetric relation here: we could investigate Section 18 without studying Section 19 but not the inverse. In order to deal properly with Section 19 we must deal with Section 18. Some problems are more artificial than others, especially as my aim here is to highlight and exhaustively organize some logical lacuna, which are brought about by the structure of the arguments. I try to show how some of them can be easily answered by Schopenhauer. Here we have more an agenda of problems to be dealt with, than a list of solutions. Consequently, the questions and the way they're ordered are more important for me in this context, than the answers.

\section{First Problem: The solipsism threat (indirect argument)}

If we really accept the robust idealism presented and defended by Schopenhauer in the first book of WWV I (as well as in his praise for Berkeley and to the first edition of the Critic of Pure Reason), solipsism and what he calls theoretical and practical egoism are indeed comprehensible constant threats to his philosophy. The problem here emerges from the legitimacy in searching for something different from my representations in the world. Radically different, we say. To which extent is it legitimate to deal with something toto genere different and independent from the subject of knowledge and his representations? The Schopenhauerian answer certainly takes into account a subjunctive or modal presupposition: a possible double knowledge of things - an understanding Schopenhauer holds as a result of the transcendental philosophy of Kant - conjugating it to the rebuttal of strong skepticism, as the last fortress of the "theoresticher Egoismus". In fact, the first justification comes from a kind of general Kantian-schopenhauerian principle, where everything can be held as a phenomenon or as a thing-in-itself. The second one comes from

making something that appears frequently in Schopenhauer's philosophy explicit, 
something just like an indirect reasoning: we have $\mathrm{x}$, because the alternative to $\mathrm{x}$ must be avoided.

Das angeschaute Objekt aber muss etwas an sich selbst sein und nicht bloß etwas für andere: denn sonst wäre es schlechthin nur Vorstellung, und wir hätten einen absoluten Idealismus, der am Ende theoretischer Egoismus würde, bei welchem alle Realität wegfällt und die Welt zum bloßen subjektiven Phantasma wird $^{11}$.

In regards to this, we must say that things have an itself, in order that the solipsism does not become a plausible alternative. In other words, things must have an itself in order that the world does not become a pure phantasmagoria to us.

\section{Second Problem: Kantian restrictions (inside the fortress!)}

The first problem is that of whether, indeed, there is the thing-in-itself or not. And if there is, the second problem here is over if it makes sense to say it is the will. It is mandatory that Schopenhauer replies with the Kantian interdiction. To deal with knowledge that is independent of our forms of knowledge demands explanation. Why do we have to assume that the thing-in-itself with its entire negative predicates is the will as suggested and defended by Schopenhauer? His answer comes from the possibility of a Standpunkt verlegen, or a change of the point of view. The key to this special knowledge of the thing-in-itself is an intimate experience of our body assured by the double perspective of the assumption: „Wir sehen schon hier, dass von außen dem Wesen der Dinge nimmermehr beizukommen ist: wie immer man auch Forschen mag, so gewinnt man nichts, als Bilder und Namen“"12. This remarkable procedure is consequent to the Kantian restrictions, and I say this due to the fact that no proof, argument, discourse or other traditional conceptual or a priori procedures could be accepted in this domain. This "knowledge" is neither a priori nor causal, because the "Leib ist ein vorstellungsgewordener Wille".

${ }^{11}$ SCHOPENHAUER, WWV II, p. 226.

${ }^{12}$ SCHOPENHAUER, WWV I, p. 142. Or even as Spierling affirms: "Der Leib ist nichts anderes als der objektivierte, zur Vorstellung gewordene Wille. (...) Aufgrund dieser Identität stehen Wille und Leib (Vorstellung gewordener Wille) in keinem kausalen Verhältnis zueinander. Vielmehr sind sowohl Aktionen aufzufassen als ein sichtbar werdendes, aber noch zu entzifferndes und zu verstehendes Ausdrucksgeschehen des Willensakten, des unsichtbaren Dings an sich" (SPIERLING, 2002, p. 65.). 
Es liegt also nicht am Mangelhaften unserer Bekanntschaft mit den Dingen, sondern am Wesen des Erkennens selbst. (...) Diesem allen zufolge wird man auf dem Wege objektiven Erkenntnis, mithin von der Vorstellung ausgehend, nie über die Vorstellung, d.i. die Erscheinung, hinausgelangen, wird also bei der Außenseite der Dinge stehen bleiben, nie aber in ihr Inneres dingen und erforschen können, was sie an sich selbst, d.h. für sich selbst, sein mögen. Soweit stimmte ich mit Kant überein. Nun aber habe ich, als Gegengewicht dieser Wahrheit, jene andere hervorgehoben, dass wir nicht bloß das erkennende Subjekt sind, sondern andrerseits auch selbst zu den erkennenden Wesen gehören, selbst das Ding an sich sind; das mithin zu jenem selbsteigenen und inneren Wesen der Dinge, bis zu welchem wir von außen nicht dringen können, uns ein Weg von innen offen steht, gleichsam ein unterirdischer Gang, eine geheime Verbindung, die uns wie durch Verrat, mit Einem Male in die Festung versetzt, welche durch Angriff von außen zu nehmen unmöglich war ${ }^{13}$.

The will as thing-in-itself as defended by Schopenhauer in Section 18 is manifested, exhibited or shown to individuals by means of a radical personal and internal experience of the body. The mistake, to which all Philosophers - says Schopenhauer here - are vulnerable, is to try to attack the fortress from outside, without noting that we are already inside of it. However, knowledge of the thing-in-itself is impossible, precisely because the knowledge vanishes where the thing-in-itself begins and the knowledge then always only deals with appearances.

Denn sie [die philosophische Wahrheit] ist nicht, wie alle jene, die Beziehung einer abstrakten Vorstellung auf eine andere Vorstellung, oder auf die notwendige Form des intuitiven, oder des abstrakten Vorstellens, sondern ist die Beziehung eines Urteils auf das Verhältnis, welches eine anschauliche Vorstellung, der Leib, zu dem hat, was gar nicht Vorstellung ist, sondern ein von diesen toto genere Verschiedenes: Wille ${ }^{14}$

\section{Third Problem: Loss of criteria (the insulated experience)}

We can clearly note in this point of his work that we have less an argument than a kind of revelation. According to Schopenhauer, the enigma, paradox or miracle key to the phenomenon is the will. The question that we have to pose is: if the experience is internal

\footnotetext{
${ }^{13}$ SCHOPENHAUER, WWV II, p. 228.

${ }^{14}$ SCHOPENHUAER, WWV I, p. 143.
} 
and intimate, what ensures that the thing-in-itself is indeed the will and not, for example, another internal state or profound feelings or any other faculty, such as love, hate, rage, angst, or despair? It may even be an interesting intellectual exercise to think of the world as having love or angst as its essence. The additional (and fascinating!) argument called to supply this inadequacy is the understanding that

Jeder wahre Akt seines Willens ist sofort und unausbleiblich auch eine Bewegung seines Leibes. Er kann den Akt nicht wirklich wollen, ohne zugleich wahrzunehmen, dass er als Bewegung des Leibes erscheint (...) Die Aktion des Leibes ist nichts Anderes, als der Objektivität d.h. zur Vorstellung gewordene Wille ist. In der Reflektion allein ist Wollen und Tun verschiedenen: in der Wirklichkeit sind sie Eins. Jeder wahre, echte, unmittelbare Akt des Willes ist sofort und unmittelbar auch erscheinender Akt des Leibes ${ }^{15}$.

To want is to act, without any intermediary, without causal relation, without consecutiveness, in an immediate and directly way. Here will/action is both the key and the criteria to this identification. "Das ist die Tatsache und das Problem". This is indeed the main argument in this section.

\section{Fourth Problem: Normativity (wahrer Akt des Willens $\leftrightarrow$ Bewegung)}

An additional problem here is a kind of normative or regulative problem. When the strength of my argument lies on the legitimacy of an act, we can ask ourselves if any kind of counter-example exists or would even be acceptable. If I will something but my body does not move or action it is it that the willing isn't "wirklich", or a genuine or legitimate willing. The not-movement works like a negative criterion for the genuine willing. By the counter-positive, if there is no act, there was no genuine willing. But I could use this same argument structure to defend any other candidate to the thing-in-itself. For example: In any case that there was no act or movement, love, hate, angst or any other profound feeling one may have felt was not genuine, not legitimate. Once we accept the presuppositions and premises of this normative argument, there is no way out. The conclusion follows automatically: This kind of argument resembles problems with well-known ad hoc

\footnotetext{
${ }^{15}$ SCHOPENHUAER, WWV I, p. 149.
} 
arguments: "It happened because it was God's will". "OK, but it did not happen at all." "Yeah, exactly, this is a clear sign that God really did not want it." God's legitimate will regulates here what happens, what does not happen, and, indeed, if anything happens at all. It will indeed always be normative criterion for what happen at all.

\section{Fifth Problem: Reduction (a multiplicity into one thing!)}

It seems that Schopenhauer makes sense out of this "choice" of the will as the thing-in-itself from amongst so many possible alternatives by using a kind of reduction presupposition. But other internal "phenomena" could be reduced in terms of will. For we can ask ourselves to which extent it is really possible to reduce a rich multiplicity of feelings, thoughts, preferences, and/or emotions into terms of a unique will. What do we gain with this kind of reduction? What do we lose? Could we, in principle, reduce will into love or love into will? As Spierling points out in this context of reduction:

Zunächst sieht sich Schopenhauer falsch verstanden, wenn die innere Wahrnehmung vom eigenen Willen schon für die angemessene Erkenntnis des Dings an sich gehalten wird. Gleichwohl ist die Erfahrung vom eigenen Wollen, so wie sie sich im Selbstbewusstsein darstellt, die für uns deutlichste Erscheinung, „Offenbarung“, „Sichtbarwerdung“ des Dings an sich. Das eigene Wollen umfasst nicht nur die Willensakten und die Entschlüsse, sondern auch alles Begehren, Streben, Wünschen, Verlangen, Hoffen, Leben, Freuen, Jubeln usw. Es gilt aber: Der Wille, so wie wir ihn in uns finden und wahrnehmen, ist nicht eigentlich das Ding an $\operatorname{sich}^{16}$.

\section{Sixth problem: Exclusion (miracle or paradox par excellence?)}

It does not seem conceptually legitimate or correct to ascribe two opposite (or even contradictory!) predicates to a same thing. This exclusion problem appears when Schopenhauer points out this kind of miracle par excellence ("schlechthin") namely, the coordination of the will and the phenomena in the same individual, using the formula: "Mein Leib und mein Wille sind Eines". Schopenhauer holds his Philosophy is the explanation of the "miracle" of the coincidence of the will and the subject in the body. Following the discursive restriction intuitively alluded to above, instead of the miracle par

${ }^{16}$ SPIERLING, 2003, p. 46. 
excellence, we could talk about a suis generis case of paradox or absurdity par excellence. Maybe this problem can be made clearer if we take the Schopenhauerian allegory about the coin into account. According to this idea, the world would be like a coin on one side of which is will while, on the other side, is representation. And it is with this allegory that Schopenhauer tries to illustrate the notion of the coordination between thing-in-itself and representation in a same body. Schopenhauer establishes the difference between thing-in-itself and phenomena and draws some consequences. Most notably, he maintains that we have a negative knowledge about the first by means of a phenomenal features subtraction or negation from the second. That means: We have the thing-in-it-self by negative determination. In a more straightforward way, we can say that phenomena are successive and extended; they are the effects or causes of other phenomena, while the thing-in-itself is a non-phenomenon, because it differentiates itself radically from these insofar as it is not temporal. Rather, will is eternal - it is not spatial, it is not a plurality, it is not a multiplicity, that is, it is one, and because it is outside the causal chain that domains the phenomena, it is grundlos. However, not being spatial does not mean that is one. Abstract things are not spatial and can be numerous, even infinite, or can belong to a plurality or multiplicity. In Schopenhauer we also have a counter-example of this assumption of uniqueness via non-spatiality: the ideas in WWV are many and they are neither spatial nor temporal.

The real side must be something toto genere different from the world as representation. This negative approach to the thing-in-itself highlights this paradox, which Schopenhauer has called "miracle". Here thing-in-itself is non-phenomenon, in a way that these two perspectives are exhaustive and exclusive - as with an instance of A and not-A. It is legitimate to question, if it is not paradoxical to think about something essentially compounded by both. Maybe this Schopenhauerian coin, which has on one side representation (A) and on the other will (not-A), cannot ultimately exist. An additional argument here is implied in the question: Why does the world have to have two perspectives and not three, four, or many others? The reason is that A and not-A are contradictory, i.e., they logically exclude any other possibility, there is no third or intermediate possibility. These two perspectives are exhaustive because they are contradictory, or radical different. "Denn welche andere Art von Dasein oder Realität 
sollten wir der übrigen Körperwelt beilegen? Woher die Elemente nehmen, aus der wir eine solche zusammensetzen? Außer dem Willen und der Vorstellung ist uns gar nichts bekannt, noch denkbar ${ }^{17 ،}$.

In the words of Rubens Torres Filho, in his inspired presentationto Cacciola's book: "The world is indeed totally representation, but also, totally will, not to be represented or destroyed: how we can sustain the challenge of this radicalization?" (p.16). My question: How can we sustain the challenge of this paradox? I guess that we can also find this "paradox" again in many other important parts of WWV, for instance, in the ethics (the "miracle" of the identity between the knowledge subject and the ethical subject) and aesthetics (identity between the individual and the pure subject). Which are the possible relationships between two aspects that are radically contrary to each other?

\section{Seventh Problem: absolute negative (the difference can be much more radical!)}

This difference between will and thing-in-it-self can be more radical and surprising than we would expect. Why does the genuine thing-in-itself, which, in the rigorous sense exists without any time barrier have to have any similarity with our will, and not with an absolute nothing, just Schopenhauer signalizes in Section 18 of WWV II?

As Schopenhaer maintains in the supplements:

Unser Wollen ist die einzige Gelegenheit, die wir haben, irgendeinen sich äußerlich darstellenden Vorgang zugleich aus seinem Innern zu verstehen, mithin das einzige uns unmittelbar Bekannte und nicht, wie alles Übrige, bloß in der Vorstellung Gegebene.(...) Demnach hat in dieser innen Erkenntnis das Ding an sich seine Schleier zwar großen Teils abgeworfen, tritt aber doch noch nicht ganz nackt aus ${ }^{18}$.

\section{Eighth Problem: Analogical argument ("the extension of the result")}

To situate its knowledge focus in a profound intimate experience with the body can be consequent to trying to escaping from Kantian restrictions, but it prepares the stage for a

\footnotetext{
17 SCHOPENHAUER, WWV I, p. 149.
}

18 SCHOPENHAUER, WWV II , p. 220. 
larger and highly recalcitrant problem. As an intimate experience takes place within one's body and one's will, how can one extend this result from an intimate experience to all the things in the world? This problem with the extension based on an analogical argument can be analyzed into others, which bring over new problems, namely: its indirect character, its invalidity, the extension scope problem and the indeterminacy of what is being extended. Here is the opportunity of a larger investigation, in order to establish some conceptual and logical distinctions.

As we already remarked, in Section 19 of WWV I, Schopenhauer is trying to extend, transfer or transmit the outlined in Section 18 (i.e. that will=thing-in-itself) to the entire world as representation, determined by the principle of sufficient reason, with its three forms - time, space and causality (already investigated by him in the first book). In spite of the problems with the identification between will and thing-in-itself by the means of an intimate experience within one's own body, I will assume the result from Section 18. We are allowed to do that, because of the already alluded asymmetry between sections 18 and 19. The intent here is to examine the extent to which this analogical argument, besides not transferring the result adequately, can contaminate the whole Schopenhauerian work; given that it is on this premise that Schopenhauer holds that the world is essentially will.

My queries are about this Übertragung, done analogically, „nach Analogie“, based on this „doppelte Erkenntnis, die wir von eigenen Leibe haben“. Schopenhauer prepares the scenario for the extension of the result. The exegetical privilege given to the body must apply to all things, because our body - just like all other things - has the forms inherent in the principle of sufficient reason. Nevertheless, a way from within stands open to us to that real inner nature of things. Just as one's body is will converted into representation, the world must be will that has become representation. Hence, according to Schopenhauer, just like an action taken by one's body is the act of the phenomenal will (i.e., will that appears in intuition), so the world must also be it. This privileged internal vision that we have from our bodies serves then as the point of resemblance for the foundation of the analogical argument. 
If we are not wrong, Schopenhauer can arrogate the Kantian heritage of a double knowledge thesis: two exhaustive "ways" of analyzing anything, including the world. Nevertheless, it seems that Schopenhauer needs something stronger than a modal or subjunctive exit for his philosophy in order, for example, to make sense of his moral theory. It looks like sometimes that he needs that this double knowledge has to be founded upon a double reality, to make sense of his insistence on a profound and essential relationship between beings. In this sense, it is not just a simple change of epistemic perspective that makes one bemitleiden with other beings but, rather, that we all essentially have something in common.

The first book of WWV I deals with explanation, etiology, morphology, abstraction, rhetoric, discursive knowledge. And the second book deals with meaning, essence, sense, reality, being, in-itself, and what looks like to demand, I hold, an independent nature or reality. This can be an interesting case of a moral intervention in the epistemology: the necessity of bringing other (moral) elements of Schopenhauerian philosophy to supply the analogical argument weakness and the solipsism refuse. "The world is not a phantasmagoria" or "I am not alone in the world" are true assumptions either because there is a coherently moral significance inherent to them or because of the moral feeling found in, and justified by, the common essence of all things.

There is an additional problem in this supplementary movement to reinforce the analogy by means of other concepts of Schopenhauer's, namely: a petitio principi. The analogical argument is used to found the moral one, while at this point we are using the moral to found the analogy. With analogical reasoning we aim to provide a good reason to see a common essence in the world, say, the will. But now we are using the very same moral that is found in the assumption of this common essence to give strength to the analogy. Somehow, Mitleid cannot be assumed as a presupposition to the analogy, because is supposed to be its "result". In other words, it is from the thesis that comes from the analogical argument, namely, that the world in itself is the will, that Schopenhauer sustains Mitleid as the truly moral ground.

There is, however, a clear problem with the analogical argument scope. How can we determine the point where the extension should stop if, indeed, it must stop at any point at all? In the examples given at the beginning of this paper I illustrated some extensions made 
through analogies which were clearly restricted to discrete domains or contexts: i.e. the cups were being used at a hypothetical party, the scientists were referring to animals with similar immune systems, and the economists were considering countries with similar organization and economical potential. In the case of Schopenhauer, the domain of analogy is purposefully unrestricted, since each abstract representation only has meaning if it stands for an intuitive instance. And, in turn, this intuitive instance only has meaning as a result of being the manifestation of the "itself" of the world. In this way, we find that all representations, objects or phenomena in the world must have - either directly or indirectly - the same itself as my body has, the same will. However, this process of stretching the result can be too permissive in its demands on resemblance or similitude because of the lack of good criteria to determinate what it means, indeed, to be alike. This fact may trivialize the analogy, especially if the criterion to determine the domain and the resemblance is something such as "everything is alike which is identical to itself" or "everything is alike which respects the logical laws". Such criteria trivialize the analogy because any one thing in any domain can clearly hold such "resemblances". Or - as in Schopenhauer's formulations - "everything that exists", as well as "everything that is extensive, consecutive", and "everything that is phenomenal" must have the same itself because it resembles my body. Excessively permissive criteria have no sensibility to distinguish the infinite spectrum or degrees of resemblance that exist.

Such an issue can also veil another question: Is an object's will stronger the more similar it is to my body? Is Will proportional to the degree of its resemblance to my body? Operating within a weaker sense of being alike - such as, a spatial sense - a situation may arise wherein, for example, I am as alike to chairs or a stones as I am to dogs or horses when we use this weak resemblance criterion. Even among human beings there are many degrees of possible resemblance. If we allow ourselves to adopt the moral intervention as an additional element to make sense out of the analogical argument necessity we could count with another criterion to the extension, not only the resemblance, but a much more restrictive criterion, radically restrictive, by the way. Although, we do not have Mitleid with a chair or a stone, it is somewhat likely that we have it with all animals, and it is possible that we do not have it with all human beings. One criterion is too permissive and insensible to differences and the other is too restrictive and impinges on the demand on generalization. 
Ultimately, we have an additional problem with the indeterminacy of what is being extended by the analogical argument. Simply, we could ask: If we assume the result from Section 18 holds, why then is it only the will and not other internal things that are extended by the arguments? What about feelings, intellect, thoughts, passions? I do not have criterion to determine the exclusivity of the will to the exclusion of other "things" which are also present in my body and could come from, or be experienced alongside, this intimate experience. And, furthermore, since it is "my" will that is being extended, what makes me believe that the result of this extension will be one unique will, shared by all things and beings, and not different "wills", so to speak? In principle, following the lines of this argument, it could be there are as many "wills" as things or beings in the world. And, at any moment, although we do not know clearly when or where that should be, the possessive "my" from "my will" has to be dropped in the extension procedure. The world's thing-in-itself is "will" and not "my will", although I reach this understanding from "my will".

As I have already mentioned in the beginning of this paper, this is an additional problem in Schopenhauer's use of the analogical argument because these do not, in general, collapse the element that is being extended with the investigated or analyzed domain. Through our examples we have seen that it is not strictly the same liquid that can be found in the cups at the party; in the same way that it is not the case that there are the same cells circulating through the immune system of all animals; and, similarly, not all emergent countries have the same economies nor do they circulate the same commodities or wares. However, it must be the same will in the essence of all things in the world, the same will that I "feel" in my body and which coordinates my acts and movements.

Right from the preface of his main work, Schopenhauer already lists some conditions for the understanding of his innovative book. Among them there is the need to read the work twice and the demand for readers to also examine some of his previous works, such as his doctoral thesis about the fourfold principle of sufficient reason. What I would like to focus on here, however, is the first demand Schopenhauer makes of the 
reader: the understanding that in $\mathrm{W}$ there is one single idea presented in an organic form. That is, like an organic system, his philosophy should be understood largely as a functional whole which articulates its single idea via different parts. In light of this, nothing like an asymmetry between its parts could be expected to be found: consequently, for example, its aesthetics only sustain itself by its ethics, or vice-verse. His axioms or principles result in theorems, in such a way that we would have axioms without theorems, but no theorem without axioms. However, the idea of logical dependence or subordination does not seem to hold in certain parts of a book which has - for editorial and publishing purposes - been presented with a beginning and an end. Schopenhauer's idea of his work's organic feature suggests that its parts sustain the whole and the whole appears through them, in a way that it gives them meaning and unity, just as with a living body, where each part contributes to the functionality of the whole, and the whole only exists and survives through a harmonious functionality of each part. Keeping this in mind, the reader comes to accept the recommendation to read the book twice because, by doing this, we can then understand the single idea that permeates everything there. As a matter of fact, the organic system of $\mathrm{W}$ cannot be approached as a system organized in terms of axioms and theorems, in which the logical hierarchy or asymmetry in the subordination and organization of its parts must be strictly respected. WWV is divided into four books, each comprising a number of sections and each section comes to corroborate the vision or perspective of this organic whole. There are two key perspectives to WWV: one of which operates within the sufficient reason principle, while the other functions outside this same principle, which manages and conditions all phenomena of the world.

The natural interpretation of all this is to affirm that Logic-theoretical features such as trivialization, inconsistencies, completeness, decidability, among others, are not relevant for the composition of an organic system, although they are central to the characterization of a formal system. This contrast is even more evident in the case of inconsistency. One suffices to bring a whole formal system to the trivialization and abandon, while in an organic system it can be harmless, if it can be localized and circumscribed. An organic system can re-establish itself or re-emerge from non-affected parts, in the case of a problem. 
Nevertheless, this is an ideal that is made fragile when we go into the details of argumentation. For, Schopenhauer's work, as with all living organisms, we can hold that there are some parts which are more important or more vital for the functionality of the whole. It is natural that some organs or structures can play the role of a functional protagonist in an organism. This fact suggests that - as some parts are more vital or more necessary than others - when key parts incur a problem; the whole system probably will also be affected by this problem. To make a long story short, a problem in this kind of privileged area, such as the heart or brain of a person, can lead the body to diseases, weakness or even to death.

There is a methodological procedure that seems to legitimate the use of an analogical extension in Schopenhauer's Philosophy: roughly speaking, the importance of having an understanding of the macro through the micro. That is, the suggestion of perceiving the general through the particular, or more specifically in our perspective here, the necessity of understanding the world through an experience of our bodies. Schopenhauer affirms this methodology legitimacy with the following:

Jeder findet sich selbst als diesen Willen, in welchem das innere Wesen der Welt besteht, so wie er sich auch als das erkennende Subjekt findet, dessen Vorstellung die ganze Welt ist, welche insofern nur in Bezug auf sein Bewusstsein, als ihren notwendigen Träger, ein Dasein hat. Jeder ist also in diesem doppelten Betracht die ganze Welt selbst, der Mikrokosmos, findet beide Seiten derselben ganz und vollständig in sich selbst. Und was er so als sein eigenes Wesen erkennt, das Selbe erschöpft auch das Wesen der ganzen Welt, des Makrokosmos: auch sie also ist, wie er selbst, durch und durch Wille, und durch und durch Vorstellung, und nichts bleibt weiter übrig. So sehen wir hier die Philosophie des Thales, die den Makrokosmos, und die des Sokrates, die den Mikrokosmos betrachtete, zusammenfallen, indem das Objekt beider sich als das Selbe aufweist ${ }^{19}$.

Accordingly, we must learn to understand nature through ourselves, not ourselves through nature ${ }^{20}$. In this perspective, that which is directly known to us must give us the

${ }_{19}$ SCHOPENHAUER, WWV I, p. 193. 
explanation for what is only indirectly known, not the converse. On this point, Janaway explains:

His [Schopenhauer's] fundamental belief is that we can make sense of our own existence and behavior by understanding our own inner essence as will, and that there is an imperative to understand or 'decipher' the world in the same way. This reveals an underlying assumption that my inner essence must be the same as that of the world at large. This is a thought which he expresses sometimes as the identity of the microcosm with the macrocosm ${ }^{21}$.

As a matter of fact, this methodological question, "to the macro departing from the micro", plays a great role in Schopenhauer's philosophy, giving additional relevance to the use of analogy, albeit not giving it validity nor the power to mitigate the other problems discussed above.

Besides this methodological justification, it may be revealing to note how Schopenhauer examines the world to make his exegetical model or unique idea, "the world as will and representation", more vivid to the readers' admiring eyes. Schopenhauer vitalizes his work by means of everyday examples taken from nature and/or naturalist books - a technique much different to how traditional Philosophy would be developed. The analogical argument used does not seem problematic at all for a philosopher with this corroborative procedure to enrich his perspective. After having established his vision of world, we can clearly see the necessity for Schopenhauer of seeing his philosophy confirmed by the natural sciences, or by empirical observations. Nothing in metaphysics that contradicts what is observable in nature - including the natural and incessant struggle for survival and perpetuation - could be accepted. Nature science would be a contiguous organ in this great Schopenhaurian all-encompassing metaphysical organism. Besides delivering relevant forms of evidence, natural sciences would deliver the ultimate criteria for metaphysics: If this does not make us understand the former better, it must be abandoned. To have a metaphysics that is not confirmed by experience would be a sufficient basis for suspicions, even more so especially if it was vulnerable to arguments.

Schopenhauer does not seem to hold the analogical argument in Section 19 of the WWV I as something merely figurative or as a metaphorical key. But the daily, or weak

${ }^{20}$ Demzufolge müssen wir die Natur verstehen lernen aus uns selbst, nicht umgekehrt uns selbst aus der Natur." (SCHOPENHAUER, WWV II, 219).

21 JANAWAY, 1999, p. 8. 
meaning of analogies, or even the use of analogy for arguments, can contaminate his work if it is held as elusive (which, in fact, it is!). It seems to me that Schopenhauer assumes that Section 19 must be reinforce with examples in WWV II through which he intends to show the supremacy of the will in human beings and in nature. The supplementation of 19 with natural examples can be anything but accidental. Nevertheless, the supplementation exposed there goes in the direction of natural research, and not of the logical analysis of the analogy components, as we would traditionally expect. Where there is a deficiency of good arguments, Schopenhauer complements his work with natural and empirical examples, rather than reorganizing the internal concepts in his philosophy to give cogency to his arguments.

This procedure is coherent with his polemical vision in respect to intellect capacity, which - for him - is radically and unavoidably subordinate to the will. This fact justifies a certain doubt of Schopenhauer's about the possible role of reason in conveying more elevated senses, meanings or values about the world. This fact is foremost visible in his non-normative aesthetics and ethics. Not entirely surprisingly, the philosopher calls the intellect "a body parasite" in first paragraph of the Section 19 of WWV II. For Schopenhauer, the intellect maintains a radical relation of subordination to the will. I believe that this viewpoint is a decisive factor behind why he does not carry out any logical refinement of the fragile analogical argument in Section 19. There is a chronic and consequent suspicion with regards to intellectual capability in producing proofs or arguments in this area. As Spierling affirms:

Entgegen der philosophischen Tradition schaltet Schopenhauer den Intellekt als den ursprünglich Ort des Willens aus. Wo immer der Intellekt auftritt, in der Metaphysik spielt er eine sekundäre Rolle, seinem Rang und seiner Kraft nach. Die Erkenntnis ist ein Licht inmitten der grenzenlosen ursprünglichen Finsternis, in der es sich verliert ${ }^{22}$.

$* * *$

A comparison of Section 19 of WWV I with its supplementation in WWV II makes us notice that the logical invalidity of analogical arguments wasn't problematic at all

22 SPIERLING, 2003, p. 68. 
for Schopenhauer, since he was secure that many things in the world - indeed, practically everything - could be listed as corroborative instances to reinforce what he was intending to do: Schopenhauer aimed to make clear to the reader that the world in itself is a blind, eternal, indestructible and grundlos will of life. "Mit allem Nachdruck greift Schopenhauer auf Tierbeispiele zurück, um den sinnlosen Kreislauf des Lebens darzustellen wie seinen Pessimismus zu verteidigen ${ }^{23}$." It sometimes seems as if Schopenhauer did not ultimately need arguments to show to his reader the truth of his thesis, needing only that the reader assume his metaphysics, through which to see through and perceive the extent to which world phenomena could be easier explained, "bis zur empirischen Naturerkenntis herabgeführt". As Schopenhauer maintains:

An solchen Erscheinungen also wird sichtbar, dass ich mit Recht als das nicht weiter Erklärliche, sondern jeder Erklärung zum Grunde zu Legende, den Willen zum Leben gesetzt habe, und dass dieser, weit entfernt, wie das Absolutum, das Unendlichen, die Idee und ähnliche Ausdrücke mehr, ein reiner Wortschall zu sein, das Allerrealste ist, was wir kennen, ja, der Kern der Realität selbst ${ }^{24}$.

This kind of procedure: "See the world through this and you will see that I am right", seems to be more cogent to Schopenhauer than any other arguments in the History of Philosophy, even strictly legitimate or valid. He did not entertain any thought of anything even resembling a threat to his Philosophy by means of the analogical argumentation. There is no contagion because there is no strict dependence.

We can now list three elements that supply relevance to the analogy used in Section 19: the corroborative forms of evidence found in nature, such as the struggle and perpetuation of living beings observable in all nature levels and areas; the methodological question (micro mirroring the macro) and the uselessness of a strictly valid proof or argument to justify the truth of his theses in an area that it is unreachable by intellectual tools, be they good or bad ones.

I believe that, working within a generous interpretation of Schopenhauer's Philosophy, withstanding all the paradoxes, invalid argumentation, inflamed rhetoric and insufficiencies provoked by a strong kind of idealism, WWV I and WWV II do not fail in

23 SPIERLING, 2003, p. 70.

24 SCHOPENHAUER, WWV II, p. 399. 
being seminal works. This is primarily due to having interesting insights and originality in relevant domains, such as: the aesthetics (foremost of which is Schopenhauer's well-known theory of musical effect); the theory of sexuality; an Ethics without normativity; his criticism of Kant; and the investigation of important aspects of nature and human beings which ultimately shows the irrationality that surrounds our actions all the time. As Janaway affirms: "It is hard for analytical philosophy to claim him as a forerunner. One reason for this, conventionally, is that he is too literary and rhetorical a writer, too much prone to metaphorical effusion and dogmatism, too little exercised by rigor and argument ${ }^{25}$ "

The analogical argument seems not to be problematic to Schopenhauer, since his logical strength is to be relevantly complemented by corroborative evidence from nature, such as the nonstop struggle for survival and perpetuity between species and between individuals of the same species. This, just like other natural phenomena, has shown Schopenhauer that the analogy conclusion, i.e., that the will in itself of the world is a blind impulse to live, is correct. Positively, we can conclude that for Schopenhauer, if his philosophy could be somehow confirmed by empirical observations and natural sciences, there would be no problematic argument that could weaken its truth. In this regard, a certain criticism in Schopenhauer presents itself clearly: it is useless or irrelevant to have proof, rigorous or not, deductive or not, in a field that is strictly impenetrable for such a rational enterprise. Moreover, to hold that will is the essence of the nature is a result of an attempt to decode its enigma via the interpretation of the will and not via a scientific or traditional analysis investigation, which would be impossible in this context. I believe that all these "conceptual and logical problems" tend to be natural consequences that come from a radical position. Schopenhauer has a Philosophy of limits: limits of thoughts, knowledge, and expression, of external and internal experiences. In this way, he has to stretch the common uses of language and reason and its traditional arguments to make them signs of something more radical (or even the most radical thing) and, in turn, making it more perspicuous than our traditional way of facing things. Pointing as he does, on the other hand, to something existing independently of our knowledge.

In a kind of historical-philosophical balance we find we gain many more interesting elucidations about the world in which we live than we lose with his radical arguments, which, although sustained are not particularly rigorous. For example, these days in contemporary philosophy will is not dealt with anymore as a simple subaltern function of

25 JANAWAY, 1999, p. 2. 
intellect but, rather, as something central to the human constitution. With WWV I and WWV II, human will and its irrationality is at the core in continental Philosophy, since Schopenhauer makes the human reason a mere Stepgap in an inhospitable, self-hungry world. As the will is not the consequence of the world, but the world is the consequence of the will.

The organism, even if ill-formed, can always heal itself, if and only if it is sufficiently vigorous.

\section{Literature}

BRANQUINHO, João (et al.). Enciclopédia de termos lógico-filosóficos. São Paulo: Martins Fontes, 2006.

CACCIOLA, Maria Lúcia. Schopenhauer e a questão do dogmatismo. São Paulo: EdUSP, 1994.

JANAWAY, Christopher (Org.). The Cambridge Companion to Schopenhauer. England: Cambridge University Press, 1999.

KANT, Immanuel. Kritik der reinen Vernunft. 2 Bände. Frankfurt am Main: Suhrkamp Taschenbuch, 1974.

SCHOPENHAUER, Arthur. Die Welt als Wille und Vorstellung. Herausgegeben von Werner Brede in zwei Werke. München: Carl Hanser Verlag 1977.

. O mundo como vontade e como representação. Tradução, apresentação, notas e índices de Jair Barboza. São Paulo: Editora UNESP, 2005.

Inc, 1966.

. The World as Will and Representation. Trad. EFJ Payne. New York: Dover Publications,

. Sobre o Fundamento da Moral. Trad. Maria Lúcia Cacciola com ensaio introdutório de Alain Roger. São Paulo: Martins Fontes, 1995.

ROGER, Alain. Ensaio introdutório. In: Sobre o fundamento da moral. São Paulo: Martins Fontes, 1995.

SPIERLING, Volker. Arthur Schopenhauer zur Einführung. Hamburg: Junius Verlag, 2002.

. Kleines Schopenhauer Lexikon. Stuttgart: Reclam, 2003.

TORRES FILHO, Rubens. Prefácio. In: Schopenhauer e a questão do dogmatismo. São Paulo: EdUSP, 1994.

WITTGENSTEIN, Ludwig. Tractatus Logico-Philosophicus. Trad. Luiz Henrique dos Santos. São Paulo: EdUSP, 1992. 
Revista Voluntas: estudos sobre Schopenhauer - $2^{\circ}$ semestre 2011 - Vol. 2 - No 2 - ISSN: 2179-3786 - pp. $185-215$.

Recebido: $21 / 12 / 11$

Received: $12 / 21 / 11$

Aprovado: 29/01/12

Approved: 01/29/12 